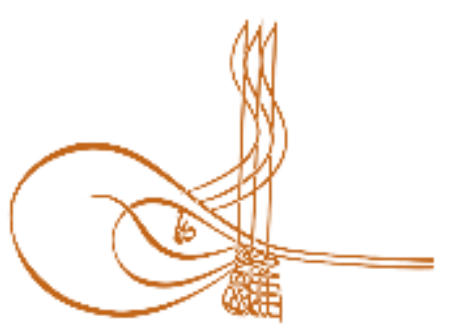

www.turkishstudies.net/turkishstudies
Turkish Studies

eISSN: $1308-2140$

Research Article / Araştırma Makalesi

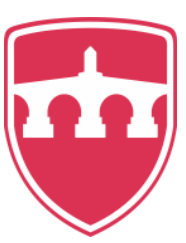

INTERNATIONAL

BALKAN

UNIVERSITY

Sponsored by IBU

\title{
Örgüt İkliminin Özel Sağlık Sektöründe Hizmet Kalitesi Üzerine Yansımalarına İlişkin Bir Çalışma
}

\author{
A Study On The Influence Of Organizational Climate On Service Excellence In Private Health \\ Segment
}

\author{
Elnur Hasan Mikail* - Hakan Çora**
}

\begin{abstract}
This research discovers the notion of organizational climate and the aforementioned effects on service quality in private health segment. With increasing competition, production quality and qualified products/services in all sectors have become increasingly important, meeting customer demands and expectations in order to achieve competitive advantage and unfulfilled customer needs discovery have come to the fore. With the introduction of health services in the private sector as well as public institutions, the concepts of quality service and customer (patient) satisfaction have gained importance in health sector. Organizations that want to improve the quality of service should first focus on the human factor they have. The satisfaction and perceived quality of service obtained from the service provided in the service sector, including the health sector, depends on the satisfaction and motivation of the providers of this service. In the health sector, where the tolerance of errors is very low, the risk of infecting employees and the intense stress associated with the work are very severe. Data for the research were gathered by survey method from 181 staff members who are employed in private clinics and healthcare facilities, i.e. hospitals that are positioned in the city of Istanbul. Attained data was analysed using IBM SPSS 16.0 and as an outcome of the research determination was that the influences of the scopes of organizational climate over quality of service were not at the identical alignment. There was a noteworthy association among concord amongst staff members and quality eminence of service. Besides, organizational ethics were also determined to have substantial effects on eminence of service. On the contrary, further scopes of organizational climate, for instance managerial support, administration's aptitude \& reliability and capacity did not have noteworthy association with eminence of service.
\end{abstract}

\footnotetext{
${ }^{*}$ Doç. Dr., Kafkas Üniversitesi, İktisadi ve İdari Bilimler Fakültesi, Siyaset Bilimi ve Uluslararası İlişkiler Bölümü Assoc. Prof. Dr., Kafkas University, Faculty of Economics and Administrative Sciences

Cite as/ Atıf: Mikail, E.,H., Çora, H. (2020). Örgüt ikliminin özel sağlık sektöründe hizmet kalitesi üzerine yansımalarına ilişkin bir çalışma, Turkish Studies, 15(1), 481-498. https://dx.doi.org/10.29228/TurkishStudies.39507

Received/Geliş: 28 Octuber/Ekim 2019

Accepted/Kabul: 25 February/Şubat 2020

Copyright $\mathbb{C}$ MDE, Turkey
} 
Structured Abstract: Introduction With increasing competition, production quality and qualified products/services in all sectors have become increasingly important, meeting customer demands and expectations in order to achieve competitive advantage and unfulfilled customer needs discovery have come to the fore. With the introduction of health services in the private sector as well as public institutions, the concepts of quality service and customer (patient) satisfaction have gained importance in health sector. Organizations that want to improve the quality of service should first focus on the human factor they have. The satisfaction and perceived quality of service obtained from the service provided in the service sector, including the health sector, depends on the satisfaction and motivation of the providers of this service. In the health sector, where the tolerance of errors is very low, the risk of infecting employees and the intense stress associated with the work are very severe. According to World Health Organization data in 2019, Turkey's fertility rate has dropped from $25 \%$ to $2.5 \%$ over the years, so it is estimated that Turkey will be one of the oldest countries in the world with a population of 6.6 million years. With its growing elderly population, it is important to provide health services in a quality manner despite the increase in diseases, maintenance problems and loss of labour. The basic idea of this study is the in what dimensions the organization's climate will affect the quality of the health service produced in private health institutions.

\section{Organizational Climate}

The organizational climate is a concept that describes the characteristics of human relations in the organization. In other words, the psychological environment prevailing in the organization is called the climate of the organization (Katz and Kahn, 1977:123). Compared to organizational culture; the climate of the organization is a definition that emphasizes the characteristics of an organization that can be immediately noticed. Anyone who visits the organization can come to an opinion about the climate of the organization when they examine the behavior of the employees towards each other and meet with the members of the organization.

If formal relations are more prominent in the current climate and friendly relationships are not approved, then there is a closed climate or a negative atmosphere. On the contrary, if there is an air of sincere friendship among employees in an organization, then this climate is more favorable.

\section{Open and Closed Organizational Climate}

The organization's climate, frequently mentioned by behavioral scientists, is an open and participatory climate. The main components of this climate are; openness in communication, finding factors that reassure subordinates, supportive leadership and an understanding that allows employees to have autonomy tendencies. In the open organization climate, there is a warm and sincere relationship between the members of the organization and a sense of unity has developed. The personal development of the members of the organization is given importance and the necessary incentives are provided for creativity and innovation. What is expected of the members of the organization is clearly defined and it is noted that these objectives are challenging but achievable. While the members of the organization have the opportunity to plan and control their own affairs, they are also given the opportunity to participate in decision-making processes. In addition, members of the organization are rewarded fairly for their work. Communication with the members of the organization in all these processes is effective, open and informative.

On the contrary, the organizational climate, in which there are no participatory processes in organizational activities, is a closed and threatening climate. In such a climate, it is observed that authoritarian rulers have an attitude that suppresses employees with their rigid attitude and willingness to comply more than usual with command links and by visible or invisible inspection methods (Young, 2004:267).

\section{Service Quality}

Service providers need to be focused on improving the quality of service due to the human factor involved in it. As with many services, quality in the field of health occurs during the interaction of patient and employee personnel. Therefore, the quality element in the service is seriously related to the performance of the employees. (Parasurman, Zeithaml and Berry, 1988).

\section{Dimensions of Service Quality}

The quality of service is an important element in order for the companies providing health care to gain competition and marketing opportunities and to maintain this situation. Grönroos (1990) said there were three important scopes and qualifications that influenced the quality of service. The scopes mentioned, in other 
words, the dimensions; dimensions about functional and technical quality and the image of the company. In this approach; Quality from technical pain is the result of what the consumer achieves in the service process, while the functional quality is the answer to how the relevant service is obtained from consumers. However, functional quality cannot be objectively evaluated by consumers

\section{Method}

The subject of this research is the effects of the organization's climate on the perceptions of the quality of service of employees in private health institutions and the research model is shown in the context. The survey method was applied to provide data for the research. During the formation of the questionnaire form used, a detailed literature study was carried out and scales were determined which were previously provided in different studies of validity and reliability. Quintuplilike type scales were used to answer surveys.

\section{Universe and sampling}

The research universe is private health sector employees and the method of sampling is easy in research. The research sample is given by two private hospitals and medical personnel working in a medical center on the European side of Istanbul province. In these organizations, a total of 300 questionnaires were distributed with the help of unit managers and 181 questionnaires were obtained as a result. Demographic features of sampling are contained in the context. According to this, there is no such time as a it is understood that the participants of the study were mostly nurses.

\section{Data Collection Tools}

The scale of the organization's climate; (1) managerial support consists of six dimensions: (2) the adequacy and consistency of management, (3) workload, (4) organizational constraints, (5) employee compliance and association, and (6) organizational ethics. Hornsby et al. for dimensions of managerial support, workload and organizational constraints. (2002), Rogg et al. for the size of management's ability and consistency. (2001), Montes, Moreno and Fernandez (2004) for the size of employee cohesion and cohesion, and Schwepker's (2001) work was used for organizational ethics. A Turkish version of the scales was made and 57 expression questionnaires were created. The answers are collected in likert 5 structure.

For service quality, parasuraman et al. (1988) developed by the SERVQUAL scale was used. Scale; physical characteristics, assurance, competence, reliability and empathy.

\section{Process}

Data from survey forms were transferred to IBM SPSS 16.0. First, the reliability and validity of the scales have been tested. Correlation analysis was performed to examine the relationships between variables and descriptive statistics were obtained. Hypothesis tests were performed by ANOVA analysis method.

\section{Findings}

The IBM SPSS 16.0 program conducted exploratory factor analysis for organizational climate and service quality scales. According to this, there is no such time as a as expected, the organization's climate scale was divided into six factors and the service quality scale was divided into five different factors.

As a result of the exploratory factor analysis, the total variance described for the variables was $73.217 \%$ for the organizational climate scale and $68.232 \%$ for the service quality scale.

\section{Results}

In this study, the effects of the organization's climate on service quality in private health organizations were discussed and as a result of separate analyses, the effects of organizational climate dimensions on service quality differed, it has been found that each dimension has no equal impact. The climate of the organization; managerial support, the adequacy and consistency of management, workload, organizational constraints, employee compliance and cohesion, and organizational ethics are discussed in six dimensions. The quality of service is; physical characteristics, assurance, competence, empathy and reliability.

The first result of the analyses is that management support in organizations has not had a significant impact on any of the service quality dimensions. This result shows that health personnel have a perception that they do not receive full managerial support. However, managerial support is very important for the formation 
of new ideas that will allow the development of the organization. Private health organizations should make a special effort to provide this support to the employees involved in their activities.

As the results show, the effects of organizational climate dimensions on service quality differ from each other. While there is a significant impact on the quality of service of organizational ethics and the harmony of the employees, it is observed that managerial support, the ability and consistency of management and the workload have no significant effect on the quality of service. Organizational constraints, on the other hand, have a meaningful relationship with only physical characteristics from service quality variables.

From this point on, it is recommended that private health sector enterprises provide more business support to employees. Managers in these organizations should be careful to provide a certain flexibility in strict rules and procedures and to be equal and consistent with all employees. An environment should be created where employees can talk to their managers about business issues. In addition, the workload on employees must be redefined. Management should express its expectations of its employees in a clear and clear position and prevent employees from experiencing uncertainty about their work. Employees should be ensured to be clearly aware of the level of performance expected of them. If these are not carried out, there may be disruptions in the service offered and the quality of service will decrease.

Keywords: Organizational climate, service quality, private health sector.

Öz: Özel sağlık sektöründe örgüt iklimi kavramı ve hizmet kalitesi üzerindeki etkileri bu çalışmada ele alınmıştır. Artan rekabet ile birlikte tüm sektörlerde kaliteli ve nitelikli ürün/hizmet üretmek giderek daha da önemli bir hal almaya başlamış, rekabet üstünlüğü sağlayabilmek için müşteri istek ve beklentilerinin karşılanması ve giderilmemiş müşteri ihtiyaçlarının keşfi ön plana çıkmıştır. Sağlık hizmetlerinin kamu kuruluşları ile birlikte özel sektörde de yoğun bir şekilde verilmeye başlanmasıyla birlikte sağlıkta kaliteli hizmet anlayışı ve müşteri (hasta) memnuniyeti kavramları önem kazanmıştır. Hizmet kalitesini yükseltmek isteyen kuruluşlar, öncelikle sahip oldukları insan faktörü üzerine odaklanmalıdır. Sağlık sektörünün de dahil olduğu hizmet sektöründe sunulan hizmetten elde edilen memnuniyet ve algılanan hizmet kalitesi, bu hizmeti sunanların yaptıkları işten memnuniyet duymalarına ve motive olmalarına bağlıdır. Hata toleransının çok düşük olduğu sağlık sektöründe, çalışanlara hastalık bulaşma riski ve işle ilgili yoğun stres çalışma koşullarını oldukça ağırlaşmaktadır. Uygulama kapsamında İstanbul'da bulunan özel sağlık kuruluşlarında görevli 181 sağlık personelinden anket yöntemiyle veri toplanmıştır. Elde edilen verilerin analizi IBM SPSS 16.0 programı vasıtasıyla yapılmış olup sonuç olarak örgüt iklimi boyutlarının hizmet kalitesi üzerindeki etkilerinin birbirinden farklılık gösterdiği tespit edilmiştir. Örgüt iklimi boyutlarından çalışanların uyumu ve birlikteliği ile örgütsel etiğin, hizmet kalitesi boyutları üzerinde istatistiksel olarak anlamlı etkilere sahip olduğu görülmüştür. Buna karşın; örgüt ikliminin yönetsel destek, yönetimin yeteneği ve tutarlılığı ile iş yükü boyutlarının hizmet kalitesi üzerinde etkisi saptanmamıştır.

Anahtar Kelimeler: Örgüt iklimi, hizmet kalitesi, özel sağlık sektörü

\section{Giriş}

Artan rekabet ile birlikte tüm sektörlerde kaliteli ve nitelikli ürün/hizmet üretmek giderek daha da önemli bir hal almaya başlamış, rekabet üstünlüğü sağlayabilmek için müşteri istek ve beklentilerinin karşılanması ve giderilmemiş müşteri ihtiyaçlarının keşfi ön plana çıkmıştır. Sağlık hizmetlerinin kamu kuruluşları ile birlikte özel sektörde de yoğun bir şekilde verilmeye başlanmasıyla birlikte sağlıkta kaliteli hizmet anlayışı ve müşteri (hasta) memnuniyeti kavramları önem kazanmıştır.

Hizmet kalitesini yükseltmek isteyen kuruluşlar, öncelikle sahip oldukları insan faktörü üzerine odaklanmalıdır. Sağlık sektörünün de dahil olduğu hizmet sektöründe sunulan hizmetten elde edilen memnuniyet ve algılanan hizmet kalitesi, bu hizmeti sunanların yaptıkları işten memnuniyet duymalarına ve motive olmalarına bağ lidır (Özgen, 1995). Hata toleransının çok düşük olduğu sağlık sektöründe, çalışanlara hastalık bulaşma riski ve işle ilgili yoğun stres çalışma koşullarını oldukça ağırlaşmaktadır (Shortell ve Kaluzny, 1983:14). Bu nedenlerle, çalışanlara verdikleri hizmetin 
karşılığını alma imkanı sunabilmek ve motivasyonlarını arttırabilmek için ücret uygulamaları sıklıkla kullanılmaktadır. Sağlık hizmetinin sunulduğu müşteriler olan hastalara her ne kadar aynı düzeyde hizmet verilmeye çalışılsa da çalışanların iş motivasyonu hizmet kalitesi algılamalarında farklılıklar yaratabilmektedir (Devebakan ve Aksarayl1, 2003).

Örgüt iklimi, 1960'lı yıllardan itibaren örgüt psikolojisi ve endüstriyel alandaki araştırmalara konu olan mühim kavramlardan biri olarak öne çıkmaktadır (Gellerman, 1960). Konunun bu denli önemli olmasının pek çok nedeni vardır. Bunlardan en önemlisi, örgüt ikliminin çalışanların psikolojik sağlığı ile bire bir ilişkili olması ve örgüt mensuplarının sahip olduğu işe dayalı tutum, davranış ve duyguları doğrudan etkilemesidir (Litwin ve Stringer, 1968:45). Öte yandan; çalışanlar açısından örgüt ikliminin sağlıklı bir çalışma ortamı oluşturduğu durumlarda, işyerinde üretkenlik, verimlilik ve performans artı̧̧ı sağlanmaktadır. Tersi durumlarda ise en başta çalışanların motivasyonu olumsuz etkilenmekte ve buna bağlı olarak işyeri etkinliği azalmaktadır.

Sağlık hizmetleri sürecine bakıldığında hizmetin üretildiği yer olan hastaneler, girdisi (hasta), dönüşüm sürecinin işleticisi (doktor) ve çıktısı (sağlıklı birey) insan olan sistemlerdir (Kavuncubaşı ve Yıldırım, 2012). Sağl1k hizmetinin karmaşık ve uzmanlık gerektiren bir alan olması itibariyle hizmetin kalitesini ve işletmenin verimliliğini ölçmek de oldukça zor olmaktadır. Örnek olarak, acil serviste günde seksen hasta bakan bir doktorla günde iki hasta ameliyat eden bir doktorun verimliliğini sadece hizmet çıktısına yani hasta sayısının çokluğuna bakarak değerlendirmek doğru olmamaktadır. $\mathrm{Bu}$ nedenle hasta memnuniyeti gibi algısal ölçümlerin de değerlendirilmesi gerekmektedir.

Dünya Sağlık Örgütü'nün 2019 yılındaki verilerine göre Türkiye'de doğurganlık hızının y1llar itibariyle $\% 25$ 'ten $\% 2,5$ 'e düşmesi nedeniyle 2054 y1lında Türkiye'nin 6,6 milyon yaşlı nüfusuyla dünyanın en yaşlı ülkelerinden biri olacağ öngörülmektedir. Artan yaşlı nüfusu ile birlikte hastalıklarda görülecek artış, bakım sorunu ve iş gücü kaybı gibi durumlara karşın sağlık hizmetlerinin kaliteli bir şekilde sunulması önem göstermektedir. Örgüt ikliminin özel sağlık kuruluşlarında üretilen sağlık hizmetinin kalitesini hangi boyutlarda etkileyeceği bu çalışmanın temel düşüncesini oluşturmaktadır.

\section{Örgüt iklimi}

Örgüt iklimi, örgütteki insan ilişkilerinin özelliklerini açıklayan bir kavramdır. Diğer bir ifadeyle örgütte hakim bulunan psikolojik ortama örgüt iklimi denilmektedir (Katz ve Kahn, 1977:123). Örgütsel kültür ile kıyaslandığında; örgüt iklimi, bir örgütün hemen fark edilebilecek özelliklerini vurgulayan bir tanımdır. Örgütü ziyaret eden herhangi bir kişi, çalışanların bir birine karşı davranışlarını incelediğinde ve örgüt üyeleri ile görüştügünde o örgütün iklimine dair bir kanıya ulaşabilir.

Eğer mevcut iklimde formal ilişkiler daha ön planda ise ve dostça kurulabilecek ilişkiler tasvip edilmiyorsa bu takdirde kapalı iklim veya olumsuz bir atmosfer söz konusudur. Bunun aksine, bir örgütte çalışanlarda arasında içten bir arkadaşlık havası hakim ise o takdirde bu iklim daha olumlu nitelenmektedir (Şişman, 1994:302).

Örgüt iklimi seneler boyunca oluşan bir birikimin ve diğer çeşitli faktörlerin ürünüdür. $\mathrm{Bu}$ iklimin, çalışanların hem işle ilgili tatminine hem de örgütün genel etkinliğine etkisi bulunmaktadır. Ancak değer yargıları kişiden kişiye değiştiğinden örgüt iklimi de çalışanlarca farklı şekilde algılanabilmektedir. Örnek olarak, kişisel gelişim ve ilerleme arzusuna sahip bir çalışan sıcak ve samimi bir örgüt iklimine daha az önem verecektir (Can, 1999:213). Çalışanların iş yerindeki uygulamalara ilişkin olarak ortamı algılayışşekilleri, örgüt iklimini yansıtır. Buna ilave olarak; örgüt ikliminde öne çıkan bir diğer konu da yöneticilerin davranışları ve onayladıkları eylemlerdir (Balcı, 1985). 
Örgüt iklimi, endüstri psikolojisinde ilk defa Gellerman (1960) tarafından dile getirilmiştir. Gellerman'a (1960) göre örgüt kişiliklerinin, insanlardaki gibi belirgin olarak sinıflandırılması mümkün olmamaktadır. Can (1999:213), örgütte hakim bulunan psikolojik ortam ile örgüt iklimi arasında kuvvetli bir ilişki olduğunu öne sürer.

Öte yandan, örgüt iklimi kavramı; ortam, çevre, kültür, hava ve duygu ile de anlamdaş olarak görülmektedir. Bu tür kavramların, örgütün iç kalitesini ve özellikle bireylerin yaşantılarını sergilediği düşünülmektedir (Karcıoğlu, 2001). Ertekin (1978) ise örgüt iklimini “örgüte kimliğini kazandıran, çalışanların davranışını etkileyen ve onlar tarafından algılanan, örgüte egemen olan özellikler dizisi” olarak tanımlamıştır. Litwin ve Stringer'e (1968:45) göre de iklim; iş çevresinde yer alan kişilerin algıladıkları ve onların motive edilmesinde etkili olan özelliklerdir.

Halpin (1966) örgüt iklimini örgütün kişiliği olarak tanımlamıştır. Bursalıŏ̆lu (1991) da benzer yönde her örgütün kendine özgü bir kişiliği olduğunu belirtmiştir. Can (1999:213) ise örgütün psikolojik ortamına vurgu yaparak tanımı psikolojik bir tabana oturtmaktadır.

\section{Örgüt ikliminin boyutları}

Örgüt iklimi ile ilgili yapılan pek çok araştırmada, örgüt iklimini oluşturan boyutlar hem örgütsel bazda (üretkenlik, verim vb.) hem de kişisel bazda (iş tatmini, stres, motivasyon vb.) incelenmiştir. Her örgüt kendi üyelerinin gereksinmelerini karşılayacak bir iklim yaratmak ve sürdürmek zorundadır. Yöneticileri buna zorlayan nedenlerin başında örgütlerin hızlı bir şekilde büyüyerek gelişmeleri ve bu süreçte yöneticilerin profesyonelleşmesi gelmektedir. Benzer şekilde, teknolojinin gelişmesi ile birlikte çalışanların daha çok beceriye sahip olması beklenmektedir. Kuşkusuz örgütsel değişim ve gelişimin kendisi de bu faktörlerin tümünü etkilemektedir (Ertekin, 1978:6).

$\mathrm{Bu}$ çalışmada örgüt iklimi; yönetsel destek, yönetimin yeteneği ve tutarlılı̆̆1, iş yükü, organizasyonel kısıtlar, çalışanların uyumu ve birlikteliği ile örgütsel etik olmak üzere altı farklı boyutta ele alınmaktadır.

Yönetsel Destek: Örgüt iklimini etkileyen faktörler içerisinde en önemli olanlardan biri çalışanın kendi yöneticilerinden gördüğü destektir. Yukarıdan aşağıya her düzeydeki yöneticiler örgütte fayda getirecek yenilikleri ve değişimleri desteklemelidir (Burton, Lauridsen ve Obel, 1999). Yöneticiler, işle ilgili yeni projeler üretebilmeleri, yenilikçi ve girişimci faaliyetlerde bulunabilmeleri için çalışanlara destek vermelidir. Bu destek yenilikçi fikirlerin geliştirilmesi ve hayata geçirilmesi için bazı kural ve prosedürlerde esneklik sağlanması şeklinde olabileceği gibi ihtiyaç halinde finansal destek verilmesi şeklinde de olabilir (Hornsby, Kuratko ve Zahra, 2002).

Yönetimin Yeteneği ve Tutarlılı̆̆ı: Yöneticilerin çalışanlara karşı tutum ve davranışları, verdikleri sözleri yerine getirip getirmemeleri, çalışanlarla olan iletişimleri ve iş dağ 1 lımında sergiledikleri tavırlar, onların bir yönetici olarak ne kadar yetenekli ve tutarlı olduklarını göstermektedir (Rogg, Schmidt, Shull ve Schmitt, 2001).

İş Yükü: Çalışanlar, üstlendikleri görevleri önceden belirlenmiş standartlara uyarak yerine getirebilmek için yeterli zamana ihtiyaç duymaktadır (Koys ve Decotiis, 1991). Çalışanların zaman kısıtı hissine kapılmaksızın çalışabilmeleri ve kendilerine işle ilgili sorunların çözümünde yeterli sürenin verilmesi, çalışanların üzerindeki iş yükünün ağırlığını göstermektedir (Hornsby vd., 2002).

Organizasyonel Kısıtlar: Çalışanların, yönetimin kendilerinden ne düzeyde bir performans beklediğini bilmeleri, yapılan işin hangi standartlara göre değerlendirileceğinin iş tanımlarında belirtilmesi veya çalışanların iş performanslarıyla ilgili olarak yöneticileriyle konuşabilmeleri iklim üzerindeki kısıtlayıcı unsurların ortadan kalkmasına yardımcı olmaktadır (Hornsby vd., 2002).

Çalışanların Uyumu ve Birlikteliği: Çalışanların gerek kurum içinde gerekse kurum dışında sahip oldukları saygın ve dostane ilişkileri, işle ilgili olarak birbirine sağladıkları destek ve 
yardımlaşma duygusu örgüt içinde daha açık bir iklim ortamının oluşması için önem arz etmektedir (Koys ve Decotiis, 1991).

Örgütsel Etik: Kurum içinde geçerli olan etik kurallar, yönetimin bu kurallara uyulmasına yönelik hassasiyeti ve uyulmaması halinde çalışanlara uygulanacak yaptırımlar örgütsel etiğin birer parçası olup örgüt ikliminin oluşması açısında önemli paya sahiptir (Schwepker, 2001).

\section{Açık ve kapalı örgüt iklimleri}

Günümüzde bazı örgütlerin başarısız olmasına karşın bazılarının gücünü koruması ve giderek arttırması çalışanların katılımına ve örgüte bağlılığına ve kendilerini işlerine adamalarına bağlıdır. Çalışanların katkısı, bağlılı̆̆ı ve örgütsel amaçlara kendilerini adaması yöneticinin yeteneklerine göre değişiklik göstermektedir. Bu noktada yöneticilere düşen en temel görev bireylerin kendilerini geliştirecekleri, iş tatmini sağlayacakları ve yüksek performans ile çalışacakları sağlıklı bir örgütün yaratılmasıdır (Barutçugil, 2004:31).

Davranış bilimciler tarafından sıklıkla bahsedilen örgüt iklimi, açık ve katılmaya teşvik eden iklimdir. Bu iklimin temel bileşenleri; iletişimde açıklık, astlara güven veren faktörlerin bulunması, destekleyici liderlik ve çalışanların özerklik eğilimlerine izin veren bir anlayıştır. Açık örgüt ikliminde örgüt üyeleri arasında sıcak ve samimi bir ilişki bulunmakta olup birlik duygusu gelişmiştir. Örgüt üyelerinin kişisel gelişimine önem verilmekte, ayrıca yaratıcılık ve yenilik konusunda da gerekli teşvik sağlanmaktadır. Örgüt üyelerinden beklenenler açık ve net olarak belirlenmiş olup bu hedeflerin zorlayıcı ancak ulaşılabilir olmasına dikkat edilmektedir. Örgüt üyeleri kendi işleri ile ilgili planlama ve kontrol olanağına sahip olmakta iken aynı zamanda karar alma süreçlerinde de kendilerine katılım imkanı verilmektedir. Ayrıca, örgüt üyeleri yaptıkları işler için adil olarak ödüllendirilmektedir. Tüm bu süreçlerde örgüt üyeleri ile kurulan iletişim etkin, açık ve bilgilendiricidir.

Bunun aksine, örgütsel faaliyetlerde katılımcı süreçlerin yer almadığı örgüt iklimi ise kapalı ve tehdit edici bir iklimdir. Böyle bir iklimde, otoriter yöneticilerin sert tavırları ve emir komuta bağlantılarına normalden fazla uymak isteği ve görünür veya görünmez denetleme yöntemleriyle çalışanları baskı altına alan bir tutum sergiledikleri gözlenmektedir (Genç, 2004:267). Bunların yanı sıra; iş güvencesinin bulunmaması, örgütte fiziksel unsurlarının çalışma ortamına uygun olmayışı, karar ile yönetim katılımı imkânlarının eksikliği, hiyerarşik, sert, merkezi ve örgüt yapısında mekanik olunması, yönetim kademesindeki ilgisizlik ve objektif olmayan tavırları ile sosyal ilişkilerde uyumsuzluk örgüt ikliminin kapalı olmasının önemli sonuçları arasındadır.

Örgüt yapısı dahilinde gözlemlenen örgütsel ikliminin ortaya çıkarttığı sonuçlar, örgüt ve işgörenlerin nezdinden farklı farklı analiz etmek gereklidir. Örgütsel taraftan incelendiğinde açık olan örgütsel iklime sahip yapılarda etkinlik ve verimliliğin yüksek olduğu, işgörenler tarafından incelendiğinde açık bir örgütsel iklim olan organizasyonlarda şahısların artmış bir motivasyon ile çalıştıkları tespit edilmiştir. Ayrıca, bu tarzdaki iklim yapılarında faaliyet gösteren kişilerde iş bağlılığında artış olmaktadır (Efil, 2002:172).

Örgüt iklimi kavramı çoğu kez örgüt kültürü kavramı ile karıştırılmaktadır. Örgüt kültürü, örgüt içinde işlerin nasıl yürüdüğünü gösteren bir faktör olup kişilerin zihninde yer alan ve davranışlarını belirleyen ideolojiyi oluşturur. Çalışan kişilere belirli bir kimlik kazandırır ve işlerin nasıl yürümesi gerektiği ile ilgili olarak yazılı olmayan ve hatta çoğu zaman konuşulmadan oluşturulmuş bir rehber olma özelliğine sahiptir. Bunun yanı sıra sosyal sistemin sürekliliğini de destekler (Cameron ve Quinn, 1999). Örgüt iklimi ise çalışanların değerleri ile kurum kültürü arasındaki uyumun en açık yansıtıcısıdır. Çalışanların örgüt kültürünü benimsediği durumlarda, örgüt iklimi daha olumlu olacaktır. Örgüt kültürünün yaygın olarak benimsenmediği durumlarda ise insanları rahatsız eden bir iklim hakim olacaktır. Örgütsel iklim, örgütsel kültüre kıyasla genellikle oldukça kısa süreli olup ve süreklilik göstermemektedir (Barutçugil, 2004:126). 


\section{Özel Sağlık Sektöründe Hizmet Kalitesi}

\section{Hizmetin tanımı}

Müşteri ihtiyaçlarını karşılamak için hizmet sektöründe görülen artış ve çeşitlilikle birlikte hizmet kavramı daha fazla önem kazanmaya başlamıştır. Kotler (1997:467) hizmet tanımını, "belirli tarafın bir başkasına sunduğu, esas olarak dokunulması mümkün olmayan ve herhangi bir sahiplikle nihayete ermeyen bir aktivite veya fayda" olarak yapar. Farklı bir deyişle; hizmet, tüketicilerin ihtiyaçları karşılamak hedefi ile oluşturulan ve maddi niteliği bulunmayan bir üründür (Kuriloff, Hemphill ve Cloud, 1993:247; Zeithaml ve Bitner, 1996:5). Hizmeti maldan ayıran temel özellikler: (1) fiziksel bir varlığın olmaması, (2) üretimle tüketimin birbirinden ayrılmaz olması, (3) müşteriye göre ya da hizmeti sunana göre değişken olması ve (4) üretildiği anda tüketilmesi yani dayanıksız olmasidır (Lovelock, 1984:30).

Diğer hizmet sektörlerindekine benzer şekilde hastanelerde verilen hizmetin soyut olmasından dolayı hizmet kalitesine ilişkin olarak psikolojik faktörler etkin rol oynamaktadır. Sağlık hizmeti, genellikle insanlar tarafından üretildiği için aynı hizmetin farklı zamanlardaki sunumu alıcıdan alıcıya ve hem de zamandan zamana farklılaşma ve değişiklik gösterir (Parasurman, Zeithaml ve Berry, 1985). Grönroos (1990:27), hizmetin etkileşim boyutuna dikkat çekerek bu etkileşimlerin müşteri ile hizmeti direk olarak yerine getiren şahıs arasında oluşabileceği gibi hizmetin verildiği ortamdaki mallar ile fiziksel çevre ile de alakalı olabileceğini ortaya koymuştur. Örnek olarak sağlık hizmetinde doktor ve hastanın etkileşimi kadar hizmetin sunulduğu yer olan hastane, poliklinik, muayenehane vb. çevre ortamın temizliği ve konforu da önemlidir (Skinner, 1990:361).

Shortell ve Kaluzny'e (1983:14) göre sağlık kuruluşlarını diğerlerinden ayıran en özellikleri: çok farklı alanlarda yer almakla birlikte uzmanlık seviyesinin yüksek olması, çeşitli meslek branşlarının faaliyetleri arasında koordinasyon gerekmesi, yapılan işlerin hemen hemen tamamının acil ve ertelenemez olması, yürütülen görevlerin hataya açık ve belirsizlik düzeyinin yüksek olması ve elde edilen sonuçların ölçümünün güç olmasıdır. Hasta statüsündeki müşteriler yalnızca hizmetteki sonucu değerlendirmeyip, veriliş biçiminin de değerlendirmesini yapmaktadırlar. $\mathrm{Bu}$ bağlamda hastalara bütüncül hizmet verilmesi gerekir. Sağllk sektöründe ürünün insan sağllğının korunması, iyileştirilmesi ve yükseltilmesi olduğu düşünüldüğünde hasta memnuniyeti ve hizmet kalitesini yükselten tüm girişimlerin bu alana uygulanma gerekliliği bulunmaktadır (Özgen, 1995).

\section{Hizmet kalitesi}

İçinde yer alan insan faktörü nedeniyle hizmet kalitesinin iyileştirilmesi için hizmet sağlayıcılara odaklanılması gerekmektedir. Birçok hizmette olduğu gibi sağlık alanında da kalite, hasta ve çalışan personelin etkileşimi surecinde ortaya çıkar. Bundan dolayı hizmetteki kalite unsuru ciddi ölçüde çalışanların performansı ile ilişkilidir. (Parasurman, Zeithaml ve Berry, 1988).

Parasurman, Zeithaml ve Berry (1994) müşteriler ile ilişkili olarak servis kalitesi için değerlendirme yapmanın ürün hakkında kalite değerlendirilmesinden oldukça daha fazla zorlu olduğu tespitini ortaya koymuştur. Bir ürünün kalitesini hammaddesi, görünüşü, tazeliği gibi fiziksel özelliklerle değerlendirmek mümkün iken hizmetler soyut ve sübjektif olduklarından kalitelerinin değerlendirilmesi çok daha zordur. Ayrıca, hizmet kalitesi algıları sadece elde edilen sonuca değil aynı zamanda sunulan hizmetin sürecine de bağlı olmaktadır.

Hizmetin soyut olması hizmet kalitesi kavramının da soyut olarak ortaya çıkmasını birlikte getirmekte ve bundan dolayı hizmetteki kalite durumu ile ilgili literatür araştırmalarında hizmette beklenen kalite ve hizmette algılanan kalite olmak üzere iki farklı tanım kullanılmaktadır. Hizmetteki beklenen kalite, müşterilerin kullanacağ 1 hizmetteki performansa yönelik tahmin ve inançlarıdır (Tek, 1999:216). Hizmetteki algilanan kalite ise müşterideki bir hizmet veya urunun üstünlüğü hakkındaki genel yargısıdır (Robledo, 2001). Ghobadian, Speller ve Jones'a (1994) göre ise algılanan 
hizmet kalitesi, müşterilerdeki hizmet kalitesine yönelik sezgileri olup müşterilerin tatmin derecesini büyük ölçüde belirlemektedir.

Parasuraman vd. (1994), hizmet kalitesini algilanan hizmet ile beklenti duyulan hizmet performansı arasındaki fark olarak değerlendirir. Buna göre; hizmet kalitesi, verilmekte olan hizmet ile müşteri beklentilerinin denkliğini hesaplayıp ölmek yolu ile tespit edilebilir. Kaliteli hizmet sunumu, müşteri beklentilerine sürekli uyum demektir. Algılanan hizmetin beklenen hizmetten düşük olduğu durumlarda, algılanan kalite de tatminkar olmaktan uzaklaşacaktır (Parasuraman vd., 1985).

Sağlık sektöründe hizmette kalite, sunulan hizmet ve servislerin bir taraftan bilimsel standartlar ve normlara diğer taraftan da kişilerin beklentilerine uyumlu şekilde ortaya konulması anlamındadır (Babakus ve Mangold, 1992). Kalitenin sağlanması için hizmeti veren sağlık çalışanının mesleki yeterliliğe yani çalıştığı alan hakkında aktüel bilime dayalı beceri ve bilgilere haiz olması, hizmeti sunma seklinin kişilerin değerlerine, norm ve beklentilerine uyumlu olması beklenir. Ayrıca verilen hizmetin kalite standart kurumları ve meslek odalarınca ortaya konulmuş standartlara da uyumluluk göstermesi beklenir (Kavuncubaşı ve Yıldırım, 2000:66).

\section{Hizmet kalitesinin boyutları}

Sağlık hizmeti veren işletmelerin rekabet ve pazarlama imkânı kazanabilmeleri ve bilahare bu durumu muhafaza edebilmeleri açısından hizmet kalitesi önemli bir öğedir. Grönroos (1990) hizmetteki kaliteye tesir eden üç mühim kapsam ve nitelik olduğunu söylemiştir. Bahsi gecen kapsamlar, diğer bir deyişle boyutlar; fonksiyonel ve teknik kalite ve firmanın imaji hakkındaki boyutlardır. Bu yaklaşımda; teknik acıdan kalite, tüketicinin hizmet sürecinde elde ettiklerinin bir sonucu iken, fonksiyonel olan kaliteden bahsedersek ilgili hizmetin tüketiciler açısından ne şekilde alınmasına olan bir cevabıdır. Bununla birlikte fonksiyonel kalite tüketiciler tarafından objektif olarak değerlendirilememektedir.

Bu derece karmaşık ve önemli olan hizmet kalitesinin ölçülmesi bilim adamlarının dikkatini çekmiş ve farklı araştırmalara konu olmuştur. Parasuraman vd. (1988) hizmet kalitesi kavramına daha geniş bir perspektiften yaklaşarak hizmet kalitesini ölçmek için SERVQUAL (Service Quality) adı verilen ayrıntılı bir ölçme yöntemi geliştirmiştir. Babakus ve Mangold (1992) ise SERVQUAL ölçeğini hastane hizmetlerinin ölçümünde kullanmış ve ölçeğin güvenilir bir değerlendirme sunduğunu belirtmiştir. SERVQUAL ölçeğinde hizmetin kalitesi belirli kriterlere göre değerlendirilmekte olup genel olarak hizmet sağlayan tüm organizasyonlarda geçerli olacak şekilde fiziksel özellikler, güvenilirlik, yeterlilik güvence ve empati boyutlarından söz edilmektedir.

Fiziksel Özellikler: Hizmet işletmelerinde algılanan hizmet kalitesinin yüksek olması için çalışan personelin fiziksel özelliklere önem verilmesi gerekmektedir (Parasuraman vd., 1985). Hastanenin fiziksel olarak rahat, konforlu ve hijyenik olması, gürültülü bir caddede konumlanmamış olması, personelin fiziksel görünümü vb. özellikler hasta memnuniyetine etki eder. Taner ve Anton (2006), Türkiye'deki devlet hastaneleri ve özel hastanelerdeki servis kalitesinin karşılaştırılmasına ilişkin çalışmalarında hastaların fiziksel özelliklere dair beklentilerinin özel hastanelerde daha iyi karşılandığını belirtmektedir.

Güvence: Bu boyut sağlık çalışanlarının bilgi ve tecrübe düzeyleri ile ilgilidir. Örnek olarak; hastalar neticede aynı tedavi hizmetini almış olsalar bile pratisyen bir hekime kıyasla profesör unvanı olan hekimden daha fazla memnun kaldıklarını ifade edebilmektedir. Ayrıca hizmeti sunan kişilerin dürüst, güvenilir ve nazik olması da hasta memnuniyetini etkilemektedir.

Yeterlilik: İhtiyaçlara yanıt verebilme olarak değerlendirilebilecek bu boyut çalışanların hizmeti sağlama konusunda hazır ve istekli olmalarını ve hızlı bir şekilde hizmeti sunmalarını ifade eder (Parasuraman vd., 1985). Özellikle kamu kuruluşlarında bürokratik işlemlerin hizmet kalitesini 
ve süratini yavaşlattığı fark edildiği için özel sağlık sektöründe bu tip işlemlerde görece azaltmaya gidilmiştir.

Güvenilirlik: Söz verilen hizmetin her seferinde vaat edildiği gibi doğru ve güvenilir bir şekilde sağlanması bu boyutu oluşturmaktadır. Güvenilirlik bakış acısında hastanelerdeki sunulması amaçlanan servisi eksiksiz sunabilmeleri önceliklidir. Doktor, hemşire vb. sağlık personeli tarafından yapılan tıbbi müdahalelerin yerinde ve zamanında olması kalite algısı için oldukça önemlidir.

Empati: $\mathrm{Bu}$ boyut hastane personelinin hastalarla anlaşabilecekleri tıbbi terminoloji içermeyen bir konuşma tarzı benimsemelerini ve onları daha iyi anlamayı sağlayan davranış sergilemelerini ifade etmektedir. Sağlık hizmetinin karmaşık ve uzmanlık gerektiren bir alan olmasından dolayı hastalar yapılacak işlemler hakkında bilgi sahibi olmamakta ve bu belirsizliğin etkisi ile stres yaşamaktadır. Bu nedenle hastalara yapılacak tüm müdahale ve işlemlerde o işlemin neden ve nasıl yapılacağı gibi bilgiler aktarılarak hasta memnuniyeti sağlanabilir.

\section{Yöntem}

Bu araştırmanın konusunu özel sağlık kuruluşlarında örgüt ikliminin çalışanların hizmet kalitesi algıları üzerindeki etkileri oluşturmakta olup araştırma modeli Şekil 1'de gösterilmiştir. Araştırmaya veri sağlamak için anket yöntemi uygulanmıştır. Kullanılan anket formunun oluşturulması aşamasında detaylı bir literatür çalışması yapılarak daha önceden geçerlilik ve güvenilirlikleri farklı çalışmalarda sağlanmış ölçekler belirlenmiştir. Anketlerin cevaplandırılmasında beşli Likert tipi ölçekler kullanılmıştır.

Şekil 1: Araştırma modeli

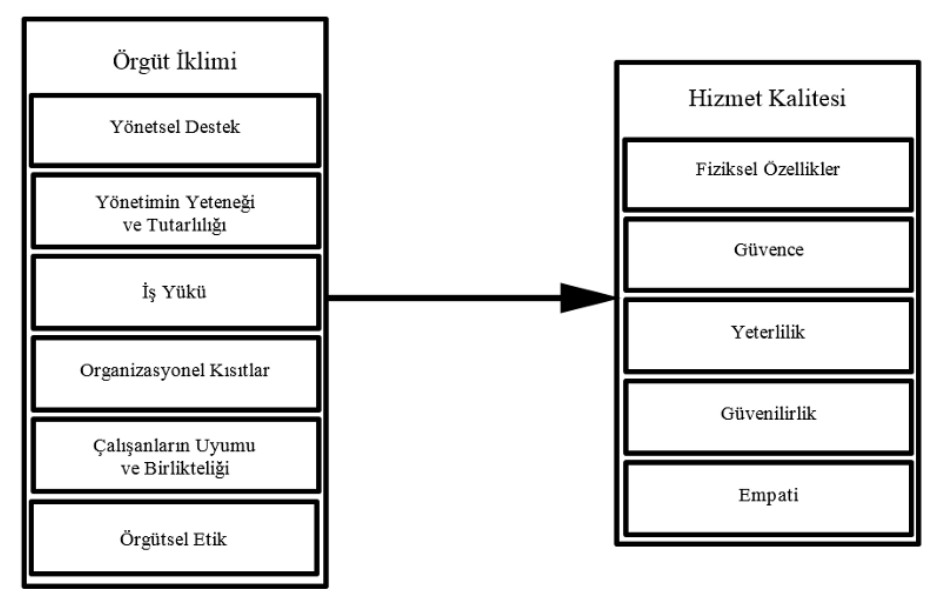

\section{Evren ve örneklem}

Araştırma evrenini özel sağlı sektörü çalışanları olup araştırmada kolayda örnekleme yöntemi tercih edilmiştir. Araştırma örneklemini ise İstanbul ili Avrupa yakasında bulunan iki özel hastane ve bir tıp merkezinde çalışan sağlık personeli oluşturmaktadır. Bu kuruluşlarda, birim yöneticileri yardımıyla toplam 300 adet anket formu dağıtılmış olup neticede tam olarak doldurulmuş 181 adet anket elde edilmiştir. Örnekleme ilişkin demografik özellikler Tablo 1'de yer almaktadır. Buna göre; araştırma katılımıılarının çoğunlukla hemşirelerden oluştuğu anlaşılmaktadır. 


\begin{tabular}{llccc}
\hline \multicolumn{2}{c}{ Tablo 1: Örnekleme ait demografik özellikler } & & \\
\hline & & $\mathrm{f}$ & $\%$ \\
\hline \multirow{2}{*}{ Görev } & Doktor & 34 & 18,78 \\
& Hemşire & 121 & 66,85 \\
& Teknisyen & 26 & 14,36 \\
\hline \multirow{2}{*}{ Çalışma Süresi } & $0-1$ & 96 & 53,04 \\
& $1-5$ & 57 & 31,49 \\
& $6-10$ & 28 & 15,47 \\
\hline \multirow{2}{*}{ Yaş } & $20-25$ & 87 & 48,07 \\
& $26-35$ & 53 & 29,28 \\
& $36-45$ & 41 & 22,65 \\
\hline \multirow{3}{*}{ Eğitim } & Lise & 47 & 25,97 \\
& Ön Lisans & 23 & 12,71 \\
& Üniversite & 67 & 37,02 \\
& Yüksek Lisans & 44 & 24,31 \\
\hline
\end{tabular}

\section{Veri Toplama Araçları}

Örgüt iklimi ölçeği; (1) yönetsel destek, (2) yönetimin yeterliliği ve tutarlılı̆̆ı, (3) iş yükü, (4) organizasyonel kısıtlar, (5) çalışanların uyumu ve birlikteliği ve (6) örgütsel etik olmak üzere altı boyuttan oluşmaktadır. Yönetsel destek, iş yükü ve organizasyonel kısıtlar boyutları için Hornsby vd. (2002), yönetimin yeteneği ve tutarlılığı boyutu için Rogg vd. (2001), çalışanların uyumu ve birlikteliği boyutu için Montes, Moreno ve Fernandez (2004), örgütsel etik boyutu için ise Schwepker'in (2001) çalışmalarından yararlanılmıştır. Ölçeklerin Türkçe uyarlaması yapılarak 57 ifadelik anket formu oluşturulmuştur. Yanıtlar Likert 5'li yapıda toplanmıştır.

Hizmet kalitesi için ise Parasuraman vd. (1988) tarafindan geliştirilen SERVQUAL ölçeği kullanılmıştır. Ölçek; fiziksel özellikler, güvence, yeterlilik, güvenilirlik ve empati boyutlarını içermektedir.

\section{İșlem}

Anket formlarından elde edilen veriler IBM SPSS 16.0 programına aktarılmıştır. Öncelikle ölçeklerin güvenilirlik ve geçerlilikleri test edilmiştir. Değişkenler arası ilişkilerin incelenmesi için korelasyon analizi yapılmış ardından betimleyici istatistikler elde edilmiştir. Hipotez testleri ise ANOVA analizleri yöntemiyle gerçekleştirilmiştir.

\section{Bulgular}

IBM SPSS 16.0 programında örgüt iklimi ve hizmet kalitesi ölçekleri için keşifsel faktör analizi yapılmıştır. Buna göre; örgüt iklimi ölçeğinin beklendiği üzere altı faktöre, hizmet kalitesi ölçeğinin ise beş ayrı faktöre ayrıldığı tespit edilmiştir.

Keşifsel faktör analizi neticesinde değişkenlere ait açıklanan toplam varyans örgütsel iklim ölçeği için \%73,217 ve hizmet kalitesi ölçeği için ise \%68,232 olarak gerçekleşmiştir.

Keşifsel faktör analizi sonuçlarına göre gruplanan ifadelerin güvenilirlik analizi gerçekleştirilmiş olup elde edilen Cronbach's $\alpha$ güvenilirlik katsayıları Tablo 2'de gösterilmektedir. Sonuçlar ölçeklerin güvenilir olduğunu göstermektedir. 
Tablo 2: Güvenilirlik analizi sonuçları

\begin{tabular}{|c|c|}
\hline Değişken & Güvenilirlik Katsayısı $(\alpha)$ \\
\hline Örgüt İklimi & 0,74 \\
\hline Yönetsel Destek & 0,80 \\
\hline Yönetimin Yeteneği ve Tutarlılı̆̆ & 0,67 \\
\hline İş Yükü & 0,80 \\
\hline Organizasyonel Kisitlar & 0,67 \\
\hline Çalışanların Uyumu ve Birlikteliği & 0,88 \\
\hline Örgütsel Etik & 0,71 \\
\hline Hizmet Kalitesi & 0,79 \\
\hline Fiziksel Özellikler & 0,71 \\
\hline Güvence & 0,87 \\
\hline Yeterlilik & 0,83 \\
\hline Güvenilirlik & 0,74 \\
\hline Empati & 0,78 \\
\hline
\end{tabular}

Değişkenler arasındaki korelasyon analizi ise Tablo 3 'te yer almaktadır.

Tablo 3: Korelasyon analizi

\begin{tabular}{|c|c|c|c|c|c|c|c|c|c|c|c|c|}
\hline & Ort. S.S. & 1 & 2 & 3 & 4 & 5 & 6 & 7 & 8 & 9 & 10 & 11 \\
\hline $1 \mathrm{YD}$ & $3,33 \quad 0,89$ & 1 & & & & & & & & & & \\
\hline $2 \mathrm{TU}$ & $3,370,57$ & $0,16^{*}$ & 1 & & & & & & & & & \\
\hline 3 İY & $2,590,82$ & $0,17 *$ & 0,03 & 1 & & & & & & & & \\
\hline $4 \mathrm{OK}$ & $3,380,59$ & 0,08 & $0,16^{*}$ & $0,42 * *$ & 1 & & & & & & & \\
\hline 5 ÇU & $3,360,69$ & 0,08 & 0,13 & $-0,03$ & 0,07 & 1 & & & & & & \\
\hline 6 ÖE & $3,48 \quad 0,48$ & 0,06 & 0,09 & $-0,04$ & $0,25 * *$ & $0,22 * *$ & 1 & & & & & \\
\hline $7 \mathrm{~T}$ & $3,770,63$ & 0,03 & $-0,02$ & 0,05 & $-0,07$ & 0,06 & $0,25 * *$ & 1 & & & & \\
\hline $8 \mathrm{G}$ & $3,40 \quad 0,54$ & 0,06 & 0,11 & 0,04 & 0,10 & $0,17 *$ & $0,38 * *$ & $0,53 * *$ & 1 & & & \\
\hline $9 \mathrm{YE}$ & $2,260,68$ & $-0,03$ & $-0,07$ & $-0,01 *$ & $-0,13$ & $-0,06$ & $-0,08$ & $-0,01$ & 0,06 & 1 & & \\
\hline $10 \mathrm{GÜ}$ & $3,61 \quad 0,50$ & 0,00 & 0,13 & $-0,02$ & $0,16^{*}$ & $0,15 *$ & $0,22 * *$ & $0,15^{*}$ & $0,26 * *$ & $0,40 * *$ & 1 & \\
\hline $11 \mathrm{E}$ & $2,710,69$ & 0,05 & $-0,06$ & 0,08 & 0,05 & $-0,00$ & 0,06 & $-0,08$ & $-0,18^{*}$ & $0,25 * *$ & $-0,30 * *$ & 1 \\
\hline $\begin{array}{l}\text { *:Kor } \\
\text { anlamlı } \\
* *: \text { Kor } \\
\text { anlamlı } \\
\text { Ort: Or } \\
\text { S.S.: St }\end{array}$ & $\begin{array}{l}\text { elasyon } \mathrm{p}< \\
1 \\
\text { elasyon } \mathrm{p}< \\
1(\mathrm{~N}=181) \\
\text { talama } \\
\text { tandart Sap }\end{array}$ & $\begin{array}{r}0,05 \mathrm{se} \\
0.10 \mathrm{se}\end{array}$ & $\begin{array}{l}\text { eviyesir } \\
\text { eviyesir }\end{array}$ & inde & $\begin{array}{l}\text { YD: Yö } \\
\text { IY: İş Y } \\
\text { ÇU: Çal } \\
\text { T: Fizik } \\
\text { YE: Yet }\end{array}$ & $\begin{array}{l}\text { uetsel De } \\
\text { ükü, OK } \\
\text { ışanların } \\
\text { sel Özell } \\
\text { erlilik, C }\end{array}$ & $\begin{array}{l}\text { estek, TU } \\
\text { : Organiz } \\
\text { Uyumu } \\
\text { likler, G: } \\
\text { GÜ: Güve }\end{array}$ & $\begin{array}{l}\text { J: Yönet } \\
\text { zasyonel } \\
\text { ve Birlil } \\
\text { Güvenc } \\
\text { nilirlik, }\end{array}$ & $\begin{array}{l}\text { imin Yet } \\
1 \text { Kisıtlar, } \\
\text { kteliği, Ö } \\
\text { E, } \\
\text { E: Empa }\end{array}$ & $\begin{array}{l}\text { eneği ve } \\
\text { Örgüt } \\
\text { ti. }\end{array}$ & $\begin{array}{l}\text { Tutarlılığ } 1 \\
\text { sel Etik, }\end{array}$ & \\
\hline
\end{tabular}

Örgüt iklimi değişkenin hizmet kalitesi boyutları üzerindeki etkileri ayrı ayrı ANOVA analizleri ile test edilmiştir. İlk olarak, yönetsel destek boyutu incelenmiş olup Tablo 4'te görüldüğü şekilde bu boyutun hizmet kalitesi üzerine istatistiksel olarak anlamlı bir etkisi saptanamamıştır $(\mathrm{p}<0,05)$. Benzer şekilde Tablo 5'te yer aldığı üzere, yönetimin yeteneği ve tutarlılığı boyutu için yapılan analizde ve Tablo 6'da yer aldığı üzere, iş yükü boyutu için yapılan analizde anlamlı bir bulguya rastlanmamıştır $(\mathrm{p}<0,05)$. 
Tablo 4: Yönetsel desteğin hizmet kalitesi boyutları üzerindeki etkisi

\begin{tabular}{llrrrrr}
\hline & & $\begin{array}{c}\text { Sum of } \\
\text { Squares }\end{array}$ & df & $\begin{array}{c}\text { Mean } \\
\text { Square }\end{array}$ & \multirow{2}{*}{ F } & \multirow{2}{*}{ Sig. } \\
\hline \multirow{2}{*}{ Fiziksel } & Gruplar aras1 & 1,134 & 8 & 0,142 & 0,338 & 0,950 \\
Özellikler & Gruplar içi & 72,079 & 172 & 0,419 & & \\
& Toplam & 73,213 & 180 & & & \\
\hline \multirow{3}{*}{ Güvence } & Gruplar aras1 & 1,80 & 8 & 0,172 & 0,567 & 0,804 \\
& Gruplar içi & 52,313 & 172 & 0,304 & & \\
& Toplam & 53,693 & 180 & & & 0,753 \\
Yeterlilik & Gruplar aras1 & 2,365 & 8 & 0,296 & 0,629 & \\
& Gruplar içi & 80,906 & 172 & 0,470 & & \\
& Toplam & 83,271 & 180 & & & 0,682 \\
Güvenilirlik & Gruplar aras1 & 1,474 & 8 & 0,184 & 0,711 & \\
& Gruplar içi & 44,590 & 172 & 0,259 & & 0,481 \\
& Toplam & 46,064 & 180 & & & \\
\hline \multirow{3}{*}{ Empati } & Gruplar aras1 & 3,658 & 8 & 0,457 & 0,945 & \\
& Gruplar içi & 83,277 & 172 & 0,484 & & \\
& Toplam & 86,936 & 180 & & & \\
\hline
\end{tabular}

Tablo 5: Yönetimin yeteneği ve tutarlılı̆̆ının hizmet kalitesi boyutları üzerindeki etkisi

\begin{tabular}{llrrrrr}
\hline & & $\begin{array}{c}\text { Sum of } \\
\text { Squares }\end{array}$ & df & $\begin{array}{c}\text { Mean } \\
\text { Square }\end{array}$ & \multirow{2}{*}{ F } & \multirow{2}{*}{ Sig. } \\
\hline \multirow{2}{*}{ Fiziksel } & Gruplar aras1 & 3,107 & 9 & 0,345 & 0,842 & 0,578 \\
Özellikler & Gruplar içi & 72,105 & 171 & 0,410 & & \\
& Toplam & 73,213 & 180 & & & \\
\hline \multirow{3}{*}{ Güvence } & Gruplar aras1 & 2,065 & 9 & 0,229 & 0,760 & 0,653 \\
& Gruplar içi & 51,627 & 171 & 0,302 & & \\
& Toplam & 53,693 & 180 & & & 0,135 \\
\multirow{3}{*}{ Yeterlilik } & Gruplar aras1 & 6,273 & 9 & 0,697 & 1,548 & \\
& Gruplar içi & 76,998 & 171 & 0,450 & & \\
& Toplam & 83,271 & 180 & & & 0,633 \\
\multirow{3}{*}{ Güvenilirlik } & Gruplar aras1 & 1,821 & 9 & 0,202 & 0,782 & \\
& Gruplar içi & 44,243 & 171 & 0,259 & & 0,975 \\
& Toplam & 46,064 & 180 & & & \\
\hline \multirow{2}{*}{ Empati } & Gruplar aras1 & 1,343 & 9 & 0,149 & 0,298 & \\
& Gruplar içi & 85,593 & 171 & 0,501 & & \\
& Toplam & 86,936 & 180 & & & \\
\hline
\end{tabular}

Tablo 6: İș yükünün hizmet kalitesi boyutları üzerindeki etkisi

\begin{tabular}{|c|c|c|c|c|c|c|}
\hline & & $\begin{array}{l}\text { Sum of } \\
\text { Squares }\end{array}$ & df & $\begin{array}{l}\text { Mean } \\
\text { Square }\end{array}$ & $\mathrm{F}$ & Sig. \\
\hline \multirow{3}{*}{$\begin{array}{l}\text { Fiziksel } \\
\text { Özellikler }\end{array}$} & Gruplar arası & 4,182 & 7 & 0,597 & \multirow[t]{3}{*}{1,497} & \multirow[t]{3}{*}{0,171} \\
\hline & Gruplar içi & 69,031 & 173 & 0,399 & & \\
\hline & Toplam & 73,213 & 180 & & & \\
\hline \multirow{3}{*}{ Güvence } & Gruplararası & 2,413 & 7 & 0,345 & \multirow[t]{3}{*}{1,163} & \multirow[t]{3}{*}{0,327} \\
\hline & Gruplar-içi & 51,280 & 173 & 0,296 & & \\
\hline & Toplam & 53,693 & 180 & & & \\
\hline \multirow{3}{*}{ Yeterlilik } & Gruplar arası & 3,602 & 7 & 0,515 & \multirow[t]{3}{*}{1,117} & \multirow[t]{3}{*}{0,354} \\
\hline & Gruplar içi & 76,998 & 173 & 0,461 & & \\
\hline & Toplam & 83,271 & 180 & & & \\
\hline \multirow{3}{*}{ Güvenilirlik } & Gruplararas1 & 1,345 & 7 & 0,192 & \multirow[t]{3}{*}{0,743} & \multirow[t]{3}{*}{0,635} \\
\hline & Gruplar içi & 44,718 & 173 & 0,258 & & \\
\hline & Toplam & 46,064 & 180 & & & \\
\hline \multirow{3}{*}{ Empati } & Gruplar aras 1 & 1,897 & 7 & 0,271 & \multirow[t]{3}{*}{0,551} & \multirow[t]{3}{*}{0,794} \\
\hline & Gruplar içi & 85,039 & 173 & 0,492 & & \\
\hline & Toplam & 86,936 & 180 & & & \\
\hline
\end{tabular}


Organizasyonel kısıtlar boyutu için yapılan analizde hizmet kalitesi boyutlarından yalnızca fiziksel özellikler ile anlamlı bir ilişki tespit edilmiştir $(F(9,171)=2,710 ; p<0,05)$. Bu sonuçlar Tablo 7'de gösterilmiştir.

Tablo 7: Organizasyonel k1sıtların hizmet kalitesi boyutları üzerindeki etkisi

\begin{tabular}{|c|c|c|c|c|c|c|}
\hline & & $\begin{array}{l}\text { Sum of } \\
\text { Squares }\end{array}$ & df & $\begin{array}{c}\text { Mean } \\
\text { Square }\end{array}$ & $\mathrm{F}$ & Sig. \\
\hline \multirow{3}{*}{$\begin{array}{l}\text { Fiziksel } \\
\text { Özellikler }\end{array}$} & Gruplar arası & 7,504 & 9 & 0,834 & \multirow[t]{3}{*}{2,710} & \multirow[t]{3}{*}{0,026} \\
\hline & Gruplar içi & 65,709 & 171 & 0,384 & & \\
\hline & Toplam & 73,213 & 180 & & & \\
\hline \multirow{3}{*}{ Güvence } & Gruplar aras1 & 1,814 & 9 & 0,202 & \multirow[t]{3}{*}{0,664} & \multirow[t]{3}{*}{0,740} \\
\hline & Gruplar içi & 51,879 & 171 & 0,303 & & \\
\hline & Toplam & 53,693 & 180 & & & \\
\hline \multirow{3}{*}{ Yeterlilik } & Gruplar aras1 & 5,971 & 9 & 0,663 & \multirow[t]{3}{*}{1,468} & \multirow[t]{3}{*}{0,164} \\
\hline & Gruplar içi & 77,300 & 171 & 0,452 & & \\
\hline & Toplam & 83,271 & 180 & & & \\
\hline \multirow{3}{*}{ Güvenilirlik } & Gruplar aras1 & 2,678 & 9 & 0,298 & \multirow[t]{3}{*}{1,173} & \multirow[t]{3}{*}{0,315} \\
\hline & Gruplar içi & 43,385 & 171 & 0,254 & & \\
\hline & Toplam & 46,064 & 180 & & & \\
\hline \multirow{3}{*}{ Empati } & Gruplar arası & 1,897 & 9 & 0,473 & \multirow[t]{3}{*}{0,979} & \multirow[t]{3}{*}{0,459} \\
\hline & Gruplar içi & 82,676 & 171 & 0,483 & & \\
\hline & Toplam & 86,936 & 180 & & & \\
\hline
\end{tabular}

Tablo 8'de yer alan çalışanların uyumu ve birlikteliği boyutu ve Tablo 9'da yer alan örgütsel etik boyutu için yapılan analizde ise hizmet kalitesinin tüm boyutları için anlamlı ilişkiler tespit edilmiştir $(\mathrm{p}<0,05)$.

Tablo 8: Çalışanların uyumu ve birlikteliğinin hizmet kalitesi boyutları üzerindeki etkisi

\begin{tabular}{|c|c|c|c|c|c|c|}
\hline & & $\begin{array}{l}\text { Sum of } \\
\text { Squares }\end{array}$ & df & $\begin{array}{l}\text { Mean } \\
\text { Square }\end{array}$ & $\mathrm{F}$ & Sig. \\
\hline \multirow{3}{*}{$\begin{array}{l}\text { Fiziksel } \\
\text { Özellikler }\end{array}$} & Gruplar arası & 26,848 & 16 & 1,678 & \multirow[t]{3}{*}{5,935} & \multirow[t]{3}{*}{0,000} \\
\hline & Gruplar içi & 46,364 & 164 & 0,283 & & \\
\hline & Toplam & 73,213 & 180 & & & \\
\hline \multirow{3}{*}{ Güvence } & Gruplar aras1 & 14,804 & 16 & 0,925 & \multirow[t]{3}{*}{3,902} & \multirow[t]{3}{*}{0,000} \\
\hline & Gruplar içi & 38,889 & 164 & 0,237 & & \\
\hline & Toplam & 53,693 & 180 & & & \\
\hline \multirow{3}{*}{ Yeterlilik } & Gruplar arası & 18,812 & 16 & 1,176 & \multirow[t]{3}{*}{2,991} & \multirow[t]{3}{*}{0,000} \\
\hline & Gruplar içi & 64,458 & 164 & 0,393 & & \\
\hline & Toplam & 83,271 & 180 & & & \\
\hline \multirow{3}{*}{ Güvenilirlik } & Gruplar aras1 & 7,512 & 16 & 0,470 & \multirow[t]{3}{*}{1,997} & \multirow[t]{3}{*}{0,016} \\
\hline & Gruplar içi & 38,551 & 164 & 0,235 & & \\
\hline & Toplam & 46,064 & 180 & & & \\
\hline \multirow{3}{*}{ Empati } & Gruplar aras1 & 22,356 & 16 & 1,397 & \multirow[t]{3}{*}{3,548} & \multirow[t]{3}{*}{0,000} \\
\hline & Gruplar içi & 64,580 & 164 & 0,394 & & \\
\hline & Toplam & 69,936 & 180 & & & \\
\hline
\end{tabular}


Tablo 9: Örgütsel etiğin hizmet kalitesi boyutları üzerindeki etkisi

\begin{tabular}{llrrrrr}
\hline & & $\begin{array}{c}\text { Sum of } \\
\text { Squares }\end{array}$ & df & $\begin{array}{c}\text { Mean } \\
\text { Square }\end{array}$ & F & \multirow{2}{*}{ Sig. } \\
\hline \multirow{2}{*}{ Fiziksel } & Gruplar aras1 & 15,798 & 6 & 2,633 & 7,980 & 0,000 \\
Özellikler & Gruplar içi & 57,424 & 174 & 0,330 & & \\
& Toplam & 73,213 & 180 & & & \\
\hline \multirow{3}{*}{ Güvence } & Gruplar aras1 & 11,586 & 6 & 1,931 & 7,979 & 0,000 \\
& Gruplar içi & 42,107 & 174 & 0,242 & & \\
& Toplam & 5,693 & 180 & & & 0,000 \\
Yeterlilik & Gruplar aras1 & 11,929 & 6 & 1,988 & 4,849 & \\
& Gruplar içi & 71,342 & 174 & 0,410 & & 0,016 \\
& Toplam & 83,271 & 180 & & & \\
\hline \multirow{3}{*}{ Güvenilirlik } & Gruplar aras1 & 7,301 & 6 & 1,217 & 5,462 & \\
& Gruplar içi & 38,763 & 174 & 0,223 & & \\
& Toplam & 46,064 & 180 & & & \\
\hline \multirow{3}{*}{ Empati } & Gruplar aras1 & 16,008 & 6 & 2,668 & 6,545 & \\
& Gruplar içi & 70,928 & 174 & 0,408 & & \\
& Toplam & 86,936 & 180 & & & \\
\hline
\end{tabular}

\section{Sonuç}

Bu çalışmada, örgüt ikliminin özel sağlık kuruluşlarında hizmet kalitesi üzerine etkileri ele alınmış olup ayrı ayrı gerçekleştirilen analizler neticesinde örgüt iklimi boyutlarının hizmet kalitesi üzerindeki etkilerinin farklılık gösterdiği, incelenen her bir boyutun aynı ölçüde etkisinin olmadığı tespit edilmiştir. Örgüt iklimi; yönetsel destek, yönetimin yeterliliği ve tutarlılığı, iş yükü, organizasyonel kısıtlar, çalışanların uyumu ve birlikteliği ve örgütsel etik olmak üzere altı boyutta ele alınmıştır. Hizmetteki kalite ise; fiziki özellik, güvence, yeterlilik, empati ve güvenilirlik kapsamları ile değerlendirilmiştir.

Analizler sonucunda elde edilen ilk netice, organizasyonlarda yönetim desteğinin hizmet kalitesi boyutlarından hiçbiri üzerinde anlamlı bir etkisinin saptanmamış olmasıdır. Bu sonuç, sağlık personelinin tam bir yönetsel destek almadığı yönünde algılara sahip olduğunu göstermektedir. Oysa örgütün gelişmesine imkan tanıyacak yeni fikirlerin oluşması için yönetsel destek oldukça önemlidir. Özel sağlık kuruluşları, faaliyetleri bünyesinde yer alan çalışanlara bu desteği sunmak için özel bir gayret göstermelidir.

Örgüt ikliminin diğer bir boyutu olan yönetimin yeteneği ve tutarlılığ 1 ile hizmet kalitesi boyutları arasında da anlamlı bir farklılık tespit edilmemiştir. Çalışanların iş hedeflerinin, görev alanlarının ve yetki sınırlarının belirlenmesi durumunda daha tutarlı bir yönetim algısı oluşmaktadır. $\mathrm{Bu}$ tanımlamaların her çalışan tarafından anlaşılacak açık bir biçimde yapılmadığı sağlık kuruluşlarında yönetimin tutum ve davranışları kişiden kişiye değişecektir.

Önceki iki boyuta benzer şekilde iş yükü ile hizmet kalitesi arasında da anlamlı bir ilişki bulunamamıştır. Özel sağlık kuruluşları, sağlık hizmeti vererek kamusal fayda sağlayan kuruluşlar olsa da aynı zamanda birer ticari işletme olduklarından personelinden en fazla verimi almak istemektedir. Bu doğrultuda mümkün olan en az personel ile mevcut işi yönetme isteği personelin iş yükünü arttırmaktadır. Oysa sağlık hizmetlerinin aksatılmaması ve hastaların süreçler arasında bekletilmemesi oldukça önemlidir.

Organizasyonel kısıtlar boyutu değerlendirdiğinde bu boyut ile hizmet kalitesinin yalnızca fiziksel özellikler boyutu arasında anlamlı bir ilişki tespit edilmiştir. Özel sağlık kuruluşu çalışanlarının işle ilgili olarak kendilerinden beklenen hizmet kalitesini yakalayabilmeleri için yeterli kaynağa, teknolojik donanıma ve ekipmana ihtiyacı bulunmaktadır. Organizasyonel kısıtlar dahilinde çalışılması hizmet kalitesini önemli ölçüde olumsuz etkileyecektir. 
Araştırma sonucunda elde edilen önemli diğer bir bulgu çalışanların uyumu ve birlikteliğinin hizmet kalitesi boyutları üzerinde anlamlı etkilerinin olduğudur. $\mathrm{Bu}$ sonuç çalışanların kişisel ilişkilerinin ve işyeri dışındaki paylaşımlarının iş ilişkilerine de yansıdığını ve hizmet kalitesi açısından olumlu çıktıların üretilmesine olanak sağladığını göstermektedir. Yalnızca mesai süresinde gereken ilişkilerin ötesinde çalışanlar arasında bu şekilde bir bağ kurulduğunda paylaşılan ortak duygular ve değerlerin çalışanların uyumunu arttıracağı ve bunun da üretilen hizmetin kalitesine olumlu yansıyacağı görülmektedir.

Son olarak, örgütsel etik boyutunun hizmet kalitesi boyutlarının tamamı üzerinde anlamlı etkilere sahip olduğu tespit edilmiştir. Ahlaki kurallara önem verilmesi hastalar açısından olduğu kadar çalışanlar tarafından da önemsenmektedir. Sağlık gibi hassas bir alanda ticari faaliyet gösteren özel sağlık kuruluşlarında etik yönde gereken adımların atılması ve bu yönde oluşturulan politikaların izlemesi gerekmektedir.

Sonuçlardan anlaşıldığ birbirinden farklılık göstermektedir. Çalışanların uyumu ve birlikteliği ile örgütsel etiğin hizmet kalitesi üzerine anlamlı bir etkisi söz konusuyken, yönetsel destek, yönetimin yeteneği ve tutarlılığ ile iş yükünün hizmet kalitesi üzerinde anlamlı bir etkisi olmadığı görülmektedir. Organizasyonel kısıtların ise hizmet kalitesi değişkenlerinden sadece fiziksel özellikler ile anlamlı bir ilişkisi bulunmaktadır.

Buradan yola çıkarak, özel sağlık sektöründe yer alan işletmelere çalışanlara işle ilgili daha fazla destek sağlamaları tavsiye edilmektedir. Bu kuruluşlarda görevli yöneticiler katı kural ve prosedürlerde belli bir esneklik sağlanmaya ve tüm çalışanlara karşı eşit ve tutarlı bir tutum içinde olmaya özen gösterilmelidir. Çalışanların yöneticileriyle işle ilgili konularda rahatlıkla konuşabileceği bir ortam yaratılmalıdır. Ayrıca, çalışanlar üzerindeki iş yükü yeniden belirlenmelidir. Yönetim, çalışanlarından beklentilerini açık ve net bir tutum içinde belirtmeli ve çalışanların işıleriyle ilgili belirsizlik yaşamasını önlemelidir. Çalışanların kendilerinden beklenilen performans seviyesini açıkça biliyor olmaları sağlanmalıdır. Bu belirtilenler gerçekleştirilmediği takdirde ise sunulan hizmette aksamalar olabilecek ve hizmet kalitesi düşecektir.

\section{Kaynakça}

Babakus, E., \& Mangold, W. (1992). Adapting the SERVQUAL Scale to Hospital Services: An Empirical Investigation. Health Services Research, 26(6), 767-786.

Balcı, A. (1985). Eğitim Yöneticisinin İş Doyumu. Yayımlanmamış Doktora Tezi, Ankara Üniversitesi, Ankara.

Barutçugil, İ. (2004). Stratejik İnsan Kaynakları Yönetimi. İstanbul: Kariyer Yayın.

Bursalıoğlu, Z. (1991). Eğitimde Yenileşme ve Demokratik Liderlik. Ankara Üniversitesi Eğitim Bilimleri Fakültesi Dergisi, 24(2), 669-674.

Burton, M. R., Lauridsen, J., \& Obel, B. (1999). Tension and Resistance to Change in Organizational Climate: Managerial Implications for a Fast Paced World. Organization Science, 7, 359-384.

Can, H. (1999). Organizasyon ve Yönetim. Ankara: Siyasal Kitabevi.

Cameron, K. S., \& Quinn, R. E. (1999). Diagnosing and Changing Organizational Culture: Based on the Competing Values Framework. Reading, MA: Addison-Wesley. https://doi.org/10.1108/jocm.2000.13.3.300.1

Devebakan N. ve Aksaraylı, M. (2003). Sağlık İşletmelerinde Algılanan Hizmet Kalitesinin SERVQUAL Skorlarının Kullanımı ve Özel Altınordu Hastanesi Uygulaması. Dokuz Eylül 
Örgüt İkliminin Özel Sağlık Sektöründe Hizmet Kalitesi Üzerine Yansımalarına İlişkin...

Üniversitesi Sosyal Bilimler Enstitüsü Dergisi, 5(1), 38-54.

https://doi.org/10.16953/deusosbil.280561

Ertekin, Y. (1978). Örgüt İklimi. Amme İdaresi Dergisi, 11(2), 16-35.

Efil, İ. (2002). Issletmelerde Yönetim ve Organizasyon. İstanbul: Alfa Basımevi.

Gellerman, S. W. (1960). People, Problems and Profits. NewYork: McGraw-Hill.

Genç, N. (2004). Yönetim ve Organizasyon-Çağdaş Sistemler ve Yaklaşımlar. Ankara: Seçkin Yayıncilik.

Ghobadian, A., Speller, S., \& Jones, M. (1994). Service Quality: Concepts and Models. International Journal of Quality \& Reliability Management, 11(9), 43-66. https://doi.org/10.1108/02656719410074297

Grönroos C. (1990). Service Management and Marketing: Managing the Moments of Truth in Service Competition. Lexington, MA: Lexington Books.

Halpin, A. W. (1966). Change and Organizational Climate. Journal of Educational Administration, $10(1), 38-81$

Hornsby, J. S., Kuratko, D. F., \& Zahra, S. A. (2002). Middle Managers' Perception of the Internal Environment for Corporate Entrepreneurship: Assessing a Measurement Scale. Journal of Business Venturing, 17(3), 253-273. https://doi.org/10.1016/s0883-9026(00)00059-8

Katz, D., \& Kahn, R. L. (1977). Örgütlerin Toplumsal Psikolojisi (çev.: H. Can ve Y. Bayar). Ankara: TODAİE

Karcioğlu, F. (2001). Örgüt Kültürü ve Örgüt İklimi İlişkisi. Atatürk Üniversitesi İktisadi ve İdari Bilimler Fakültesi Dergisi, 15(1-2), 265-283. https://doi.org/10.18657/yecbu.80040

Koys, D. J., \& Decotiis, T. A. (1991). Inductive Measures of Psychological Climate. Human Relations, 44(3), 265-285. https://doi.org/10.1177/001872679104400304

Kotler, P. (1997). Marketing Management: Analysis, Planning, Implementation and Control. New Jersey: Prentice Hall.

Kuriloff, A. H., Hemphill, M. J., \& Cloud, D. (1993). Starting and Managing the Small Business. Singapore, McGraw-Hill.

Kavuncubaşı, Ş. ve Yıldırım, S. (2012). Hastane ve Sağllk Kurumları Yönetimi. Ankara: Siyasal Kitabevi.

Lovelock, C. H. (1984). Services Marketing: Text, Cases \& Reading. Englewood Cliffs, NJ: Prentice Hall.

Litwin, G., \& Stringer, R. (1968). Motivation and Organizational Climate. Boston: Harvard University Press.

Montes, F. J. L., Moreno, A. R., \& Fernandez, L. M. M. (2004). Assessing the Organizational Climate and Contractual Relationship for Perceptions of Support for Innovation. International Journal of Manpower, 25(2), 167-180. https://doi.org/10.1108/01437720410535972

Özgen H. (1995). Sağlık Hizmetlerinde Kalite Nedir? Hasta Tatmini Boyutuyla İlgili Bir Değerlendirme. Toplum ve Hekim, 10(69-70), 47-53.

Parasuraman, A., Zeithaml, V. A., \& Berry, L. L. (1985). A Conceptual Model of Service Quality and Its Implication. Journal of Marketing, 49(Fall), 41-50. https://doi.org/10.1177/002224298504900403 
Parasuraman, A., Zeithaml, V., \& Berry, L. L. (1988). SERVQUAL: A Multi-Item Scale for Measuring Consumer Perceptions of Service Quality. Journal of Retailing, 64 (Spring), 1240.

Parasuraman, A., Zeithaml, V. A., \& Berry, L. L. (1994). Reassesment of Expectations as a Comparison Standard in Measuring Service Quality: Implications for Further Research. Journal of Marketing, 49(4), 253-268. https://doi.org/10.2307/1252255

Robledo, M. A. (2001). Measuring and Managing Service Quality: Integrationg Customer Expectations. Managing Service Quality, 11(4), 22-31. https://doi.org/10.1108/09604520110379472

Rogg, K. L, Schmidt, D. B., Shull, C., \& Schmitt, N. (2001). Human Resource-Practices, Organizational Climate and Customer Satisfaction. Journal of Management, 27, 431-449. https://doi.org/10.1177/014920630102700403

Schwepker, C. H. (2001). Ethical Climate's Relationship to Job Satisfaction, Organizational Commitment, and Turnover Intention in the Salesforce. Journal of Business Research, 54, 39-52. https://doi.org/10.1016/s0148-2963(00)00125-9

Skinner, S. J. (1990). Marketing. Boston: Houghton Mifflin Company.

Shortell, S. M., \& Kaluzny, A. D. (1983). Organization Theory and Health Care Management. (Ed. Shortell \& Kaluzny). Health Care Management: A Text in Organization Theory and Behavior. New York, John Wiley \& Sons. https://doi.org/10.1002/hpm.4740010116

Şişman, M. (1994). Örgüt Kültürü. Eskişehir: Anadolu Üniversitesi Yayınları.

Taner, T., \& Antony, J. (2006). Comparing Public and Private Hospital Care Service Quality in Turkey. Leadership in Health Services, 19(2), 1-10. https://doi.org/10.1108/13660750610664991

Tek, Ö. B. (1999). Pazarlama İlkeleri: Global Yönetimsel Yaklaşım, Türkiye Uygulamaları. İstanbul: Beta Yayınları.

Zeithaml, V. A., \& Bitner, M. J. (1996). Services Marketing. Singapore: McGraw-Hill. 